Gaabriel Tavits, Dr. iur.

University of Tartu, Estonia

\title{
COLLECTIVE LABOUR RELATIONS AND DIGITAL ECONOMY - DO THEY CO-EXIST?
}

\begin{abstract}
Summary
The world of work has changed rapidly. New forms of employment (platform employment, crowd-working, fulfilling small gigs) are on the increase. Different views are voiced about the application of individual employment law to the new forms of employment. On that topic, uncertainty prevails. At the same time, the new-workers are unionising and they are organising collective actions against the platform-owners, while the legal grounds of such collective actions remain unclear. Do these collective actions constitute a part of collective labour law or they are outside of the scope of application? The recent case law of the European Committee of Social Rights shows that the selfemployed and the new-workers also could have an opportunity to profit from the legal regulation of collective labour relations.

The article examines the importance of collective labour relations for the new forms of employment (new workers) and the possible applicability of collective labour law to the new forms of employment.
\end{abstract}

Keywords: new forms of employment, platform-employment, collective labour relations, self-employed, collective agreement

\section{Introduction}

The changing nature of labour relations leaves no option that the legal regulation of labour relations remains unchanged. There have always been two levels in the legal regulation of labour relations: on the one hand, individual labour relations are important, while on the other hand, the collective labour relations also matter, including the right to conduct collective negotiations, to establish trade unions and other representative organisations for the protection of the rights. Collective labour relations have always played an important role in the regulation of labour relations. A social dialogue has always been relevant in the development of labour relations and also the socio-political relations on the level of the European Union in general. ${ }^{1}$

Whereas the discussion about the regulation of individual work performance comprises different viewpoints (whether including employees or not) ${ }^{2}$, meanwhile,

About the social dialogue and consultations with trade unions and employers associations, see: https://ec.europa.eu/social/main.jsp?catId=329\&langId=en [last viewed November 1, 2019].

2 Davidov G. Who is a Worker? Available at: https://papers.ssrn.com/sol3/papers.cfm?abstract id $=783465$ [last viewed October 31, 2019]; see also: Tavits G. Scope of Application of Estonian Labour Legislation. Juridica International, No. 1, 1996, pp. 114-125. Available at: https:// www.juridicainternational.eu/index.php?id=12431 [last viewed October 31, 2019]. 
no legal discussion with regard to the interests of a collective of the new employees has so far gained focus. Concurrently, certain forms of work performance have been consolidated in the collective protection of interests (e.g., ride-sharing service via a corresponding platform), but one question has not been solved yet: whether and in which range is it possible to discuss the collective protection of interests and the collective regulation of these interests?

This article is divided into three parts. The first chapter of the article handles the new forms of work performance and the options for legal regulation of such new forms of work performance. The second chapter addresses particular matters, including who can form collective in the meaning of the contemporary labour law and who is entitled to the right to organise collective actions among other things. The third chapter analyses the legal rights of new workers (e.g. workers of the platform) to organise collective activities and conduct negotiations for the conclusion of the collective agreement.

\section{New forms of work performance - what is new in those?}

The development of new forms of work performance is related to a variety of different developments in the society. An important role is played by the development of different digital devices accompanied by options of faster data communication. ${ }^{3}$ Whereas the earlier new digital solutions were implemented in the military industry and households, today the new digital solutions have become an integral part of work and daily life. Digital options form the basis for and create possibilities for the simplification of work performance. For example, let us take the performance of distant work and its legal regulation. Distance work has become possible, as the worker does not have to be present at a certain workplace and the employer does not have to check on the employee's presence all the time. It is important that the worker is reachable for the job-related communication and all the necessary assignments are completed. Also, in connection with the development of digital devices new forms of work performance have been invented, including crowdworking (cloudworking) or working via the platform. In case of all these forms of work performance, the main question is: on which contractual basis is the work performed - whether, in the meaning of labour law, it comprises an employee and an employment contract or is it another kind of contractual relation in case of which the regulation of employment contract cannot be adopted.

Work performance via a platform (e.g. Uber, Yandex, etc.) also plays a notable role here. Hereby, the most important question is whether the platform can be an employer or not, ${ }^{4}$ and whether the worker, who gains a chance of employment and

3 Data Storage History and Future. Available at: https://www.datarecoverygroup.com/articles/datastorage-history-and-future [last viewed November 1, 2019].

4 Prassl J., Risak M. Uber, Taskrabbit, \& Co: Platforms as Employers? Rethinking the Legal Analysis of Crowdwork. Available at: https://papers.ssrn.com/sol3/papers.cfm?abstract id=2733003 [last viewed November 11, 2019]. 
earning income, has to be handled in the meaning of the labour law as an employee, being a subject of all rights and obligations thereof.

On the level of the European Union, attention should be paid to the new forms of work performance based on two documents adopted by the EU: digital single market strategy ${ }^{5}$ and the importance of sharing economy. ${ }^{6}$ The impact of both documents also allows discussing new forms of work performance and their possible development.

In respect to the new forms of work performance, the main problem seems to be the legal regulation of the work performance - must it definitely be a relation subject to the employment contract or is it another kind of contractual relation? The legal literature and the available court practice shows controversy. Workers of different platforms have been regarded as employees; ${ }^{7}$ however, there have also been judicial decisions, in which the workers have not been regarded as employees. ${ }^{8}$ Hereby, it is also possible to refer to a legal act, e.g. California Act $(\text { Bill 5 })^{9}$, which lists the criteria forming the basis according to which it is possible to identify the employee. According to the aforementioned act, all workers engaged in the new form of work performance have to be entitled to the status of an employee. The statements in the corresponding literature do not overlap. It has been stated that also according to this document it is possible to exclude the employee's status in the new forms of work performance. ${ }^{10}$

The new forms of work performance have practically been discussed for quite some time, attempting to establish who is an employee and who is not. Therefore, there is nothing new or unprecedented in the approach. However, the ways how the work is done and also the working conditions have significantly changed. In case of new forms of work performance, the use of working time has become substantially more flexible, so that practically no restrictions are imposed on the working time. The term of the employment contract has also changed, because in addition to the employment contract concluded for an indefinite term, numerous options of

5 A Digital Single Market Strategy for Europe, $\operatorname{COM(2015)~} 192$ final, European Commission. Available at: https://eur-lex.europa.eu/legal-content/EN/TXT/?qid=1447773803386\&uri=CELE X:52015DC0192 [last viewed October 28, 2019].

6 A European agenda for the collaborative economy, $\operatorname{COM}(2016) 356$ final, European Commission. Available at: http://ec.europa.eu/DocsRoom/documents/16881/attachments/2/translations [last viewed October 28, 2019].

7 See e.g., Uber loses appeal over driver employment rights, 20 December 2018. Available at: https:// www.theguardian.com/technology/2018/dec/19/uber-loses-appeal-over-driver-employmentrights [last viewed October 28, 2019]; Madrid court rules Deliveroo couriers are employees and not freelancers, 24 July 2019. Available at: https://www.euronews.com/2019/07/23/madrid-courtrules-deliveroo-couriers-are-employees-and-not-freelancers [last viewed October 28, 2019].

8 See e.g. Russian gig economy violates worker rights with society's tacit acceptance. Available at: https://ohrh.law.ox.ac.uk/russian-gig-economy-violates-worker-rights-with-societys-tacit-acceptance/ [last viewed November 11, 2019].

9 AB-5 Worker status: employees and independent contractors. Available at: https://leginfo. legislature.ca.gov/faces/billTextClient.xhtml?bill_id=201920200AB5 [last viewed November 11, 2019].

10 See https://techcrunch.com/2019/09/10/gig-worker-bill-ab-5-passes-in-california/ [last viewed November 11, 2019]. 
short-term work performance have been added, concurrently, it may be observed that the so-called gigs have gained an increasing importance. Consequently, the nature of labour relation has changed considerably - the labour relations are no longer established for an indefinite term, and at the same time it cannot be assumed that the work is performed for 40 hours a week, at the time precisely appointed by the employer.

\section{Who may form the collective in the meaning of collective labour law?}

Collective labour relations have always played an eminent role. The corresponding conventions of $\mathrm{ILO}^{11}$ and the Social Charter of the Council of Europe, ${ }^{12}$ and the Charter of Fundamental Rights of the European Union ${ }^{13}$ foresee several different options for the formation of collective labour relations; however, these documents do not specify by whom the collective may be formed. The abovementioned documents do not directly indicate that collective labour relations and their legal regulation must be ensured to employees working on the basis of an employment contract. Taking into account the time, when, e.g., the corresponding ILO conventions were adopted, and then considering the implementation practice of ILO conventions and the Social Charter of the Council of Europe, the so-called regular labour relations characterised by existing employment contract is kept in mind. Hence, considering the historical and teleological interpretation, the collective of employees can be formed by people who are working on the basis of an employment contract. All the other workers could not be regarded as a party in collective labour relations because it is not possible to handle them as a "collective", which can obtain the right to participate in negotiations for the conclusion of a collective agreement and for the application of rights accompanying it.

\section{Situation in Estonia}

The legal regulation of collective labour relations in Estonia is based on the fact that employees and employers may be parties in collective labour relations and may form a collective of workers in its legal meaning. According to $₫ 29$ of

11 C087 - Freedom of Association and Protection of the Right to Organise Convention, 1948 (No. 87). Available at: https://www.ilo.org/dyn/normlex/en/f?p=NORMLEXPUB:12100:0::NO::P12100 ILO_CODE:C087 [last viewed October 31, 2019]; C098 - Right to Organise and Collective Bargaining Convention, 1949 (No. 98). Available at: https://www.ilo.org/dyn/normlex/en/f?p=NO RMLEXPUB:12100:0::NO::P12100_ILO_CODE:C098 [last viewed October 31, 2019].

12 Art. 5 and 6 of the European Social Charter (revised) [in the wording 02.01.2019]. Available at: https://rm.coe.int/168007cf93 [last viewed October 31, 2019].

13 Art. 28 of the Charter of the Fundamental Rights of the European Union [in the wording 02.01.2019]. Available at: https://www.europarl.europa.eu/charter/pdf/text_en.pdf [last viewed October 31, 2019]. 
the Constitution of the Republic of Estonia ${ }^{14}$, collective labour relations are entitled to both the employees and the employers. Hereby, in the meaning of the Estonian constitution, subjects to an employment contract are kept in mind, because only the existence of an employment contract ensures the employee's and the employer's legal status.

According to the Collective Agreements' Act $^{15}$, the collective agreement is concluded by the collective of employees and the employer or the federations of employees and the federations of the employers.

According to the Collective Labour Dispute Resolution Act, ${ }^{16}$ a collective labour dispute isa disagreement between the employees and the employer, which may occur upon concluding the collective agreement or be connected with the performance of the collective agreement.

According to the Employees' Trustee Act $^{17}$, the trustee is elected by those employees, who do not belong to a trade union. At the same time the trustee can be elected by those employees who are employed on the basis of an employment contract. Other workers, who do not work on the basis of the employment contract, cannot elect a trustee for the purpose that the person would represent their rights collectively.

Hence, according to the legal regulation of the collective labour relations in Estonia it may be stated that a party of collective labour relations has to be an employee and an employer. Collective labour relations can be formed only then, when an employment contract is concluded. Without an employment contract no collective labour relations are possible.

The terms - the employee and the employer have not been unanimously defined in the Estonian legislation today. The aforementioned terms may be derived from the definition of the employment contract. According to $\$ 1$ of the Employment Contracts $\mathrm{Act}^{18}$, one party - the employee undertakes to perform work while being subject to another party's (employer) management and supervision. The employer undertakes to pay the employee wages for that. features:

Therefore, the term of the employment contract comprises three relevant

1) the employee works while being dependent from the employer's orders

2) the employer pays the employee wages for such activity

${ }_{14}$ S 29. The Constitution of the Republic of Estonia. Available at: https://www.riigiteataja.ee/en/ eli/521052015001/consolide [last viewed October 28, 2019].

15 Collective Agreements' Act. Available at: https://www.riigiteataja.ee/en/eli/518062018002/ consolide [last viewed October 31, 2019].

16 Collective Labour Disputes Resolution Act. Available at: https://www.riigiteataja.ee/en/ eli/526062018001/consolide [last viewed October 31, 2019].

17 Employees' Trustee Act. Available at: https://www.riigiteataja.ee/en/eli/505052017006/consolide [last viewed October 28, 2019].

18 Employment Contracts' Act. Available at: https://www.riigiteataja.ee/en/eli/509052019005/ consolide [last viewed November 1,2019]. 
3) the legal status of the employee and the employer can be created on the basis of the employment contract only.

Other legal acts regulating labour relations also proceed from the terms of $₫ 1$ of the Employment Contracts Act and the legal acts regulating the right to social protection. Hereby, it can be concluded that according to the contemporary collective labour law a collective can be formed only by employees, whose employer has concluded an employment contract. If no employment contract is concluded with the person performing work, the persons providing work do not form a collective and the need for the legal regulation of collective labour relations (the right to carry out collective negotiations, the right to organise collective activities) is absent.

\section{Collective employment relationships and new forms of work}

\subsection{Position of the European Committee of Social Rights}

Particular attention in the new forms of employment has been paid to the characteristics of individual labour law and the need for regulation. Case law that varies from state to state have, for example, led to different treatment of ride-sharers who work through mediation of platforms. They have been sometimes recognized as employees, ${ }^{19}$ while in some cases people working on the platform cannot be considered as employees. ${ }^{20}$ Similarly, the Court of Justice of the European Union has not treated Uber as a new service provider, but as an ordinary taxi company. ${ }^{21}$

Although there is an ambiguity in the definition of worker in individual labour law, it does not interfere with the organization of collective action by workers who do not work under an employment contract. Thus, in January 2018, there was a service stoppage ${ }^{22}$ by platform Taxify drivers in Estonia. The reason for the stoppage was that drivers were dissatisfied with the change in pricing policy that would have reduced driver fees. As a result of the service disruption, the Taxify (now Bolt) platform

19 See e.g., Uber loses appeal over driver employment rights, 20 December 2018. Available at: https:// www.theguardian.com/technology/2018/dec/19/uber-loses-appeal-over-driver-employmentrights [last viewed October 21, 2019]; Madrid court rules Deliveroo couriers are employees and not freelancers, 24 July 2019. Available at: https://www.euronews.com/2019/07/23/madridcourt-rules-deliveroo-couriers-are-employees-and-not-freelancers [last viewed October 28, 2019].

20 See e.g. Russian gig economy violates worker rights with society's tacit acceptance. Available at: https://ohrh.law.ox.ac.uk/russian-gig-economy-violates-worker-rights-with-societys-tacitacceptance/ [last viewed November 11, 2019].

${ }^{21}$ European Court of Justice case No. C-434/15, Asociación Profesional Elite Taxi v. Uber Systems Spain SL. Available at: https://eur-lex.europa.eu/legal-content/EN/TXT/?uri=CELEX\%3A62015 CJ0434 [last viewed November 11, 2019].

22 Hundred Taxify drivers are striking against new price policy: we are like taxi-monkeys, who work themselves every week in minus, that Taxify will win the price-war! 26 January 2018 . Available at: https://arileht.delfi.ee/news/uudised/fotod-ja-video-sadakond-taxify-juhti-streigivad-uue-hinnapoliitika-vastu-me-oleme-nagu-taksoahvid-kes-tootavad-end-iga-nadal-miinusesse-et-taxify-voi$\mathrm{d}$ ? id=80920773\&fbclid=IwAR1RxcFKdqNK3e4WCO2MtggBZpp3QAKzVyFxZRDQjyYEvPNq DdLa7xyUwwg [last viewed October 28, 2019]. 
operator withdrew its pricing policy changes. In October 2019, the platform Bolt drivers participated in demonstrations in London ${ }^{23}$ to further develop price policy elements, as well as to stop platform manipulation with algorithms. Both of the aforementioned actions clearly show that new workers have started to assert their rights collectively and have also realized that, if it is possible to take collective action against platform managers, it can also entail legal consequences.

However, the questions regarding the nature of such outages remain legally unanswered. Is it a strike in terms of collective labour law or is it just a public meeting, for example ${ }^{24}$ ? As we have seen above, the legal regulation of employment relationships applies when it comes to an employment contract. Similarly, the legal regulation of collective employment relationships is related to the legal protection of employees under employment contracts. Therefore, workers who work on the platforms and who do not have a contract of employment are not considered as subjects to whom collective labour rights apply.

Although platform employees have emerged as the first associations ${ }^{25}$ to defend their interests, the existing legal framework does not allow them to be guaranteed the rules governing collective labour regulation.

Given the current understanding of the regulation of collective employment relationships, it can be argued that the regulation of collective employment relationships is excluded for those working on the platform. Nevertheless, in the light of the case law of the European Committee of Social Rights, this situation seems to be coming to an end. This assertion is supported by the decision of the European Social Rights Committee of 12.12.2018, in which the European Social Rights Committee had to formulate its position on whether freelance musicians (self-employed) wishing to enter into a service agreement can do so on the basis of Art. 6 of the European Social Charter. ${ }^{26}$ In other words, the European Committee of Social Rights had to formulate a position on whether any economic activity and the collective agreements concluded within it were to be regarded as a collective agreement with all the respective consequences.

In that particular case, it was a collective complaint allowed by the European Social Charter. That collective complaint was brought by the Irish Congress of Trade Unions against the Republic of Ireland. The complaint was supported by the fact

23 Bolt minicab drivers to protest 'unjust' working conditions. Available at: https://www.taxi-point. co.uk/post/bolt-minicab-drivers-to-protest-unjust-working-conditions [last viewed November 2, 2019].

24 Tavits G. The Right to Collective Action in Labour Relations in Estonia: Is the Right to Organise a Strike Guaranteed? Juridica International, No. 1, 2014, p. 218. Available at: https://www. juridicainternational.eu/index.php?id=15417 [last viewed October 28, 2019].

25 International Rideshare Drivers Association. Available at: https://www.internationalridesharedriv ersassociation.com/ [last viewed October 1, 2019], see also Rideshares United, https://driversunited.org/about [last viewed October 31, 2019].

26 European Committee of Social Rights, Decision on Merits, 12.12.2018, case: Complaint No. 123/2016. Available at: https://www.coe.int/en/web/european-social-charter/processedcomplaints/-/asset_publisher/5GEFkJmH2bYG/content/no-123-2016-irish-congress-of-tradeunions-v-ireland?inheritRedirect=false [last viewed October 1, 2019]. 
that the Irish Competition Act does not provide for the possibility of collective agreements for self-employed persons, since under that law such agreements would be contrary to the provisions of the Competition Act. Although the Republic of Ireland amended its competition law and in certain cases allowed self-employed to enter into collective agreements, the Irish Congress of Trade Unions found that the restrictions imposed by competition law were too restrictive and that not all individual entrepreneurs could enter into collective agreements. In its ruling, the European Committee of Social Rights concluded that the Irish Competition Act does not, however, infringe the right of self-employed to conclude a collective agreement. At the same time, the European Committee of Social Rights formulated one important principle for the future. According to the European Committee of Social Rights:

The Committee considers that self-employed workers having no substantial influence on the content of their contractual conditions, if they were to bargain individually, must therefore be given the right to bargain collectively. ${ }^{27}$

The Committee also has stated:

Moreover, the Committee emphasises that collective mechanisms in the field of work are justified by the comparably weak position of an individual supplier of labour in establishing the terms and conditions of their contract. This contrasts with competition law where the grouping of interests of suppliers endanger fair prices for consumers.

The Committee continued:

In establishing the type of collective bargaining that is protected by the Charter, it is not sufficient to rely on distinctions between worker and self-employed, the decisive criterion is rather whether there is an imbalance of power between the providers and engagers of labour. Where providers of labour have no substantial influence on the content of contractual conditions, they must be given the possibility of improving the power imbalance through collective bargaining.

(p. 38 of the Decision). ${ }^{28}$

According to that decision, the European Committee on Social Rights endorses the view that it does not matter whether it is a contract of employment or not, but rather whether or not the worker (in this case, the individual entrepreneur) has the opportunity to influence the content of the contract. In the absence of such an opportunity, a self-employed or a group of self-employed must also be able to

27 European Committee of Social Rights, Decision on Merits, 12.12.2018, case: Complaint No. 123/2016. Available at: https://www.coe.int/en/web/european-social-charter/processedcomplaints/-/asset_publisher/5GEFkJmH2bYG/content/no-123-2016-irish-congress-of-tradeunions-v-ireland?inheritRedirect=false [last viewed October 1, 2019].

28 European Committee of Social Rights, Decision on Merits, 12.12.2018, case: Complaint No. 123/2016. Available at: https://www.coe.int/en/web/european-social-charter/processedcomplaints/-/asset_publisher/5GEFkJmH2bYG/content/no-123-2016-irish-congress-of-tradeunions-v-ireland?inheritRedirect=false [last viewed October 1, 2019]. 
conclude collective agreements, and such agreements do not infringe the relevant provisions of competition law. By that decision, the European Committee of Social Rights essentially extended the scope of collective labour law and allowed collective agreements to be concluded for non-employees too. This is a rather landmark decision that will significantly change the perceptions that so far have prevailed in collective labour relations. The decision above, as a whole, forces the Member States which have ratified the European Social Charter to review their national law in order to preclude situations where national competition law would preclude the conclusion of such agreements and restrict the ability of self-employed to bargain collectively on the terms of service.

In addition to being able to negotiate the terms of service collectively, it must also be accompanied by the opportunity of collective action (the right to strike). Although the position of the European Social Rights Committee has not been formulated on the right to organize strikes, the right to organize strikes is an important part of collective bargaining. Thus, opening up the legal opportunity to conclude collective agreements also entails the right to organize collective actions.

\subsection{Legal situation in Estonia}

Under Estonian law, a collective agreement can be concluded by a collective of employees or an association of employees. Similarly, the right to organize collective actions - strikes and lock-outs - is vested in the collective of employees or employers. In both cases, it is a prerequisite that there is an employment relationship and that relationship also forms the basis for the collective of workers who must be provided with the relevant rights.

According to Estonian law, the difference in collective labour relationships remains for civil servants. Under the Civil Service Act ${ }^{29}$, officials cannot organize strikes. However, the Civil Service Act does not provide for any exceptions everyone who is appointed as an official, is not entitled to strike. Nevertheless, it is not prohibited for officials to negotiate collectively with a view to concluding a collective agreement. If the negotiating parties that are officials (or trade unions representing the interests of officials) fail to reach the necessary agreement, the officials will not be able to use retaliation measures.

Under Estonian competition law ${ }^{30}$, agreements between undertakings, coordinated practices and decisions of associations of undertakings are prohibited, including:

1) the direct or indirect determination of prices and other trading conditions in relation to third parties, including fixing of prices, tariffs, charges,

29 Civil Service Act. Available at: https://www.riigiteataja.ee/en/eli/525032019003/consolide [last viewed November 1, 2019].

30 Competition Act. Available at: https://www.riigiteataja.ee/en/eli/510042019001/consolide [last viewed October 31, 2019]. 
mark-ups, discounts or rebates, subscriptions, surcharges, interest rates, rent or rental fees;

2) restriction of production, service, goods market, technical development or investment;

3) sharing of goods market or source of supply, including foreclosure of, or attempt to foreclose, third party goods market;

4) exchange of information which is harmful to competition;

5) agreeing to apply dissimilar conditions to equivalent agreements, thereby placing business partners at a competitive disadvantage;

6) imposing upon a third party a condition for entering into an additional obligation not related to the object of the agreement.

Although the Competition Act imposes restrictions on the conclusion of certain types of agreements, the Competition Act also exempts the cases, in which agreements can be concluded and these agreements do not distort competition or the market situation. Pursuant to Section 4 of the Competition Act, ${ }^{31}$ the above restrictions do not apply in the following cases:

1) the agreement contributes to improving the production or distribution of goods or to promoting technical or economic progress or to protecting the environment by allowing consumers a fair share of the resulting benefit;

2) does not impose on the undertakings concluding the agreement, acting in concert or taking a decision, the restrictions which are not indispensable to the attainment of the above objectives; does not impose on undertakings which conclude, coordinate or take decisions restrictions which are not indispensable to the attainment of the objectives referred to above;

3) does not allow undertakings which conclude, coordinate or take decisions to eliminate competition in respect of a substantial part of the product market.

The above exceptions do not foresee that self-employed workers can enter into collective agreements with the aim of jointly agreeing, for example, on the cost (price) of service. Rather, under Estonian law, the self-employed person can be presumed to be subject to the aforementioned price restriction and other trading conditions. It means that if the self-employed wish to negotiate these terms collectively and conclude a collective agreement, this is a situation where the agreement significantly reduces the conditions of competition. Since such collective agreement significantly impairs the conditions of competition, such agreements are not permissible. In addition, the Competition Act provides for a financial penalty if a legal person infringes the terms of the Competition Act. In the event of an infringement of free competition, a fine of up to EUR 400000 may be imposed. ${ }^{32}$

31 Competition Act. Available at: https://www.riigiteataja.ee/en/eli/510042019001/consolide [last viewed October 31, 2019].

32 Competition Act. Available at: https://www.riigiteataja.ee/en/eli/510042019001/consolide [last viewed October 31, 2019]. 
Current legislation in Estonia does not support the possibility for self-employed persons, or other non-employed workers to enter into collective agreements in order to determine the prices and conditions for the provision of the service. Such agreements harm the market situation and violate the requirements of competition law. According to this principle, platform-based employees fall into the same category. These workers are also legally precluded from entering into collective agreements to negotiate or amend the terms of service.

The collective actions that have taken place so far, though not leading to agreements, have resulted in the platform manager refusing to set new prices or change the terms of service. Such collective actions are not excluded under Estonian law and do not violate competition law or other statutory requirements.

\section{Conclusions}

The new forms of employment entail the need for review of the existing labour law. So, the context of individual labour law does not provide for any clarity for the status of new worker - for instance, do workers who use platforms to find work and to do work need the same protection as regular employees?

With regard to collective labour relations, the development seems to be different. Persons who work by means of platforms have formed associations to represent their interests, and the first collective actions to protect rights have taken place. Although those who work through platforms may not necessarily be working under an employment contract, the European Committee on Social Rights considers that it is possible to view them collectively and to assert rights arising from collective employment relationships. This option implies that the Member States have to start analysing competition laws, since collective agreements not concluded by trade unions may be contrary to competition law and therefore become unacceptable.

\section{BIBLIOGRAPHY}

\section{Literature}

1. A Digital Single Market Strategy for Europe, $\operatorname{COM(2015)} 192$ final, European Commission. Available at: https://eur-lex.europa.eu/legal-content/EN/TXT/?qid=1447773803386\&uri= CELEX:52015DC0192 [last viewed October 28, 2019].

2. A European agenda for the collaborative economy, $\operatorname{COM}(2016) 356$ final, European Commission. Available at: http://ec.europa.eu/DocsRoom/documents/16881/attachments/ $2 /$ translations [last viewed October 28, 2019].

3. AB-5 Worker status: employees and independent contractors. Available at: https://leginfo. legislature.ca.gov/faces/billTextClient.xhtml?bill_id=201920200AB5 [viewed 01.11.2019.]; https://techcrunch.com/2019/09/10/gig-worker-bill-ab-5-passes-in-california/ [last viewed November 1, 2019].

4. Bolt minicab drivers to protest 'unjust' working conditions. Available at: https://www. taxi-point.co.uk/post/bolt-minicab-drivers-to-protest-unjust-working-conditions [last viewed November 2, 2019]. 
5. Data Storage History and Future. Available at: https://www.datarecoverygroup.com/articles/ data-storage-history-and-future [last viewed November 1, 2019].

6. Davidov G. Who is a Worker? Available at: https://papers.ssrn.com/sol3/papers. cfm?abstract_id=783465 [last viewed October 31, 2019].

7. European Committee of Social Rights, Decision on Merits, 12.12.2018, case: Complaint No. 123/2016. Available at: https://www.coe.int/en/web/european-social-charter/ processed-complaints/-/asset_publisher/5GEFkJmH2bYG/content/no-123-2016-irishcongress-of-trade-unions-v-ireland?inheritRedirect=false [last viewed October 1, 2019].

8. European Court of Justice case No. C-434/15, Asociación Profesional Elite Taxi v. Uber Systems Spain SL. Available at: https://eur-lex.europa.eu/legal-content/EN/TXT/?uri= CELEX\%3A62015CJ0434 [last viewed November 11, 2019].

9. Hundred Taxify drivers are striking against new price policy: we are like taxi-monkeys, who work themselves every week in minus, that Taxify will win the price-war!, 26 January 2018. Available at: https://arileht.delfi.ee/news/uudised/fotod-ja-video-sadakond-taxify-juhtistreigivad-uue-hinnapoliitika-vastu-me-oleme-nagu-taksoahvid-kes-tootavad-end-iga-nadalmiinusesse-et-taxify-void?id=80920773\&fbclid=IwAR1RxcFKdqNK3e4WCO2MtggBZpp3 QAKzVyFxZRDQjyYEvPNqDdLa7xyUwwg [last viewed October 28, 2019].

10. International Rideshare Drivers Association. Available at: https://www.internationalridesharedriversassociation.com/ [last viewed October 1, 2019].

11. Prassl J., Risak M. Uber, Taskrabbit, \& Co: Platforms as Employers? Rethinking the Legal Analysis of Crowdwork. Available at: https://papers.ssrn.com/sol3/papers.cfm?abstract id $=2733003$ [last viewed November 1, 2019].

12. Russian gig economy violates worker rights with society's tacit acceptance. Available at: https://ohrh.law.ox.ac.uk/russian-gig-economy-violates-worker-rights-with-societys-tacitacceptance/ [last viewed November 1, 1919].

13. Rideshares United, https://drivers-united.org/about [last viewed October 31, 2019].

14. Spanish Courts Rule Against Deliveroo: 'Riders Are Not Self-Employed', 26.08.2019. Available at: https://www.forbes.com/sites/anagarciavaldivia/2019/08/26/spanish-justicerules-against-deliveroo-riders-are-not-self-employed/\#2da1a2e45781 [last viewed October 31, 2019].

15. Tavits G. Scope of Application of Estonian Labour Legislation. Juridica International, No. 1, 1996, pp. 114-125. Available at: https://www.juridicainternational.eu/index.php?id=12431 [last viewed October 31, 2019].

16. Tavits G. The Right to Collective Action in Labour Relations in Estonia: Is the Right to Organise a Strike Guaranteed? Juridica International, No. 1, 2014, p. 218. Available at: https:// www.juridicainternational.eu/index.php?id=15417[last viewed October 28, 2019].

17. Uber loses appeal against landmark UK workers' rights ruling, 19.12.2018. Available at: https://www.cnbc.com/2018/10/31/uber-loses-appeal-against-landmark-uk-workers-rightsruling.html [last viewed October 31, 2019].

\section{Legislative acts}

1. C087 - Freedom of Association and Protection of the Right to Organise Convention, 1948 (No. 87). Available at: https://www.ilo.org/dyn/normlex/en/f?p=NORMLEXPUB:12100:0 ::NO::P12100_ILO_CODE:C087 [last viewed October 31, 2019].

2. C098 - Right to Organise and Collective Bargaining Convention, 1949 (No. 98). Available at: https://www.ilo.org/dyn/normlex/en/f?p=NORMLEXPUB:12100:0::NO::P12100_ILO_ CODE:C098 [last viewed October 31, 2019]. 
3. Charter of the Fundamental Rights of the European Union [in the wording 02.01.2019]. Available at: https://www.europarl.europa.eu/charter/pdf/text_en.pdf [last viewed October 31, 2019].

4. Civil Service Act. Available at: https://www.riigiteataja.ee/en/eli/525032019003/consolide [last viewed November 1, 2019].

5. Collective Agreements Act. Available at: https://www.riigiteataja.ee/en/eli/518062018002/ consolide [last viewed October 31, 2019].

6. Collective Labour Disputes Resolution Act. Available at: https://www.riigiteataja.ee/en/ eli/526062018001/consolide [last viewed October 31, 2019].

7. Competition Act. Available at: https://www.riigiteataja.ee/en/eli/510042019001/consolide [last viewed October 31, 2019].

8. Constitution of the Republic of Estonia. Available at: https://www.riigiteataja.ee/en/ eli/521052015001/consolide [last viewed October 28, 2019].

9. Employment Contracts' Act. Available at: https://www.riigiteataja.ee/en/eli/509052019005/ consolide [last viewed November 1, 2019].

10. Employees' Trustee Act. Available at: https://www.riigiteataja.ee/en/eli/505052017006/ consolide [last viewed October 28, 2019]. 